\title{
Profil Sepsis Anak di Pediatric Intensive Care Unit Rumah Sakit Umum Pusat Sanglah Denpasar - Bali
}

Dyah Kanya Wati, I Nyoman Budi Hartawan, Ida Bagus Gede Suparyatha, Dewi Sutriani Mahalini, I Gusti Ayu Putu Eka Pratiwi, I Made Gede Dwi Lingga Utama

Departemen Ilmu Kesehatan Anak Fakultas Kedokteran Universitas Udayana/ RSUP Sanglah, Denpasar

Latar belakang. Sepsis dan klasifikasinya merupakan kondisi yang mengancam nyawa dengan angka kematian mendekati $10 \%$ dari seluruh pasien dengan sepsis dan syok septik Angka kematian ini akan meningkat pada anak dengan minimal satu penyakit komorbid yang menyertai dan mendekati angka $76 \%$ berdasarkan jumlah organ yang mengalami disfungsi. Sampai saat ini belum ada data pasti yang menunjukan prevalensi dan karakteristik pasien dengan sepsis di Unit Perawatan Intensif (UPIA) Rumah Sakit Umum Pusat (RSUP) Sanglah Denpasar.

Tujuan. Mengetahu prevalensi serta karakteristik pasien dengan sepsis pada pasien anak berusia 0-18 tahun di Unit Perawatan Intensif (UPIA) Rumah Sakit Umum Pusat (RSUP) Sanglah Denpasar tahun 2018.

Metode. Penelitian ini merupakan penelitian deskriptif retrospektif dengan menggunakan data rekam medis RSUP Sanglah yang dikumpulkan meggunakan metode purposive sampling dengan kriteria inklusi dan eksklusi.

Hasil. Penelitian ini sudah berjalan selama 1 tahun dari bulan Januari 2018 sampai dengan Desember 2018. Sampel yang dikumpulkan sebanyak 28 sampel. Kategori usia bayi tertinggi merupakan sampel yang digunakan, yaitu sebesar 57,1\%. Diagnosis terbanyak adalah syok sepsis sebesar 60,7\%. Skor pediatric sequential failure assesment (pSOFA) didapatkan dengan rerata sebesar 5,94.

Kesimpulan. Prevalensi sepsis di UPIA Rumah Sakit Umum Pusat Sanglah Denpasar pada tahun 2018 didominasi oleh pasien dengan kategori usia bayi (<2 tahun). Sari Pediatri 2019;21(3):152-8

Kata kunci : sepsis, syok, UPIA, pSOFA, anak

\section{Sepsis Profile in Children at Pediatric Intensive Care Unit Sanglah Hospital Denpasar - Bali}

Dyah Kanya Wati, I Nyoman Budi Hartawan, Ida Bagus Gede Suparyatha, Dewi Sutriani Mahalini, I Gusti Ayu Putu Eka Pratiwi, I Made Gede Dwi Lingga Utama

Background. Sepsis and its classification are life-threatening conditions with mortality rates approaching $10 \%$ of all patients with sepsis and septic shock, this mortality rate will increase in children with at least one comorbid disease that accompanies and approaches $76 \%$ based on the number of dysfunctional organs. Until now there is no definitive data that shows the prevalence and characteristics of patients with sepsis in the Pediatric Intensive Care Unit (PICU) Rumah Sakit Umum Pusat (RSUP) Denpasar.

Objective. Knowing the prevalence and characteristics of patients with sepsis in pediatric patients aged 0-18 years in the Intensive Care Unit (UPIA) Rumah Sakit Umum Pusat (RSUP) Denpasar in 2018.

Methods. This study is a retrospective descriptive study using medical records from Sanglah Hospital collected using purposive sampling method with inclusion and exclusion criteria.

Result. This research has been running for one year from January 2018 to December 2018, and 28 samples were collected. The baby age category is the highest in the sample used, which is equal to $57.1 \%$. With the most diagnosis, septic shock was $60.7 \%$. The pediatric sequential failure assessment (pSOFA) score was obtained with a mean of 5.94 .

Conclusion. The prevalence of sepsis at the PICU Sanglah Central Hospital Denpasar in 2018 is dominated by patients with the age category of infants (<2 years). Sari Pediatri 2019;21(3):152-8

Keywords: sepsis, shock, PICU, pSOFA, pediatric 
S epsis dan klasifikasinya merupakan kondisi yang mengancam nyawa dan pada tahun 1995 didapatkan 750.000 orang terdiagnosis sepsis di Amerika Serikat. ${ }^{1}$ Menurut data tersebut angka kematian yang disebabkan sepsis selalu meningkat setiap tahunnya. ${ }^{2}$ Pada pasien anak, sepsis dan syok septik merupakan diagnosis utama untuk infeksi yang tidak terkompensasi. Kurang lebih 29.000 anak berusia kurang dari lima tahun meninggal setiap harinya karena infeksi dan pada akhirnya terdiagnosis sepsis .

Pada tahun 2002, 32\% anak di negara berkembang dirawat di ruang intensif dengan diagnosis sepsis dan syok septik, dengan angka mortalitas sebesar $57,3 \%{ }^{3} \mathrm{Di}$ Amerika Serikat didapatkan bahwa insiden sepsis berat pada tahun 1995 adalah 5,3 kasus setiap 1000 anak usia kurang dari satu tahun dan 0,2 kasus setiap 1000 anak dengan rentang usia 5 hingga 14 tahun. Angka kematianini mendekati $10 \%$ dari seluruh pasien dengan sepsis dan syok septik. Angka kematian ini akan meningkat pada anak dengan minimal satu penyakit komorbid yang menyertai dan mendekati angka $76 \%$ berdasarkan jumlah organ yang mengalami disfungsi. Di Korea Selatan, prevalensi sepsi berat pada anak yang di rawat di Unit Perawatan Intensif Anak (UPIA) kurang lebih 7,3\% dengan angka kematian pada pasien ini sebesar $64,6 \% .{ }^{4}$

Di Indonesia, prevalensi sepsis anak usia 0-18 tahun belum banyak dilaporkan. Namun, menurut data yang diperoleh di rumah sakit Sutomo, kasus dengan sepsis berat pada usia dewasa sebesar $27,08 \%$, syok septik $14,58 \%$, sedangkan $58,33 \%$ sisanya hanya jatuh dalam keadaan sepsis. ${ }^{5}$ Sementara menurut Riskesdas RI tahun $2007,{ }^{6}$ sepsis neonatorum mempunyai angka kematian sebesar 20,5\%.

Berdasarkan pemaparan tersebut penulis terdorong untuk melakukan penelitian guna mencari prevalensi serta karakteristik pasien dengan sepsis pada pasien anak berusia 0-18 tahun di Unit Perawatan Intensif (UPIA) Rumah Sakit Umum Pusat (RSUP) Sanglah Denpasar tahun 2018.

\section{Metode}

Penelitian ini merupakan penelitian deskriptif retrospektif. Digunakan data rekam medis RSUP Sanglah yang dikumpulkan menggunakan metode non probability sampling, yaitu purposive sampling. Sampling dilakukan berdasarkan keputusan penulis menurut populasi yang mewakili dalam rentang waktu
Oktober - Desember 2018 di Rumah Sakit Umum Pusat Sanglah, sebagai pusat kesehatan tersier. Perizinan dan informed consent didapat dari bagian penelitian dan pengembangan RSUP Sanglah Denpasar.

Semua anak yang terdiagnosis sepsis/syok septik dan dirawat di unit perawatan intensif anak di antara periode Januari - Desember 2018. Data diambil menggunakan rekam medis dengan kriteria inklusi untuk dapat diikutsertakan pada penelitian ini. Kriteria inklusi, antara lain, 1) anak berusia 0 hari - 18 tahun ketika dirawat di ruang perawatan intensif anak, 2) terdiagnosis sepsis/syok septik, baik saat baru masuk UPIA atau selama perawatan di UPIA RSUP Sanglah Denpasar. Pasien dengan data rekam medis tidak lengkap akan dieksklusi dari penelitian.

Variabel penelitian yang digunakan, yaitu, usia, jenis kelamin, infeksi sepsis menurut penyakit dasar, lama rawat, dan angka kematian. Usia dihitung berdasarkan tanggal, bulan, tahun kelahiran dan dinyatakan secara lengkap dalam bulan dan tahun. Subjek penelitian dipilih pada kelompok usia di atas 0 hari hingga 18 tahun.

Pemilihan batas atas usia 18 tahun adalah terkait dengan batas kelompok usia anak yang dapat dirawat di bangsal anak, khususnya unit perawatan intensif anak, skala pengukuran numerik. Infeksi menurut penyakit dasar, yaitu pembagian infeksi sepsis yang disebabkan oleh penyakit sebelumnya, skala pengukuran kategorikal. Lama rawat, yaitu lama rawat pasien dalam hari dengan diagnosis sepsis berserta klasifikasinya di unit perawat intensif anak, skala pengukuran numerik. Angka kematian, yaitu banyaknya pasien yang meninggal dunia setelah terdiagnosis sepsis, skala pengukuran kategorikal.

Data yang didapatkan dari sampel, kemudian dikumpulkan dan diolah ke dalam perangkat lunak, kemudian dianalisis menggunakan program komputer. Hasil Penelitian kemudian disajikan dalam bentuk rerata \pm deviasi standar untuk data kontinyu yang berdistribusi normal atau median (range interkuartil) untuk data kontinyu yang tidak berdistribusi normal. Angka absolut (persentase) dipilih untuk menunjukkan data kategorik atau nominal. Data demografi dan klinis dipresentasikan secara deskriptif dan dalam bentuk Tabel atau Grafik.

\section{Hasil}

Penelitian ini sudah berjalan selama satu tahun dari bulan Januari 2018 sampai dengan Desember 2018 
dan sampel yang dikumpulkan sebanyak 28 sampel. Data yang dikumpulkan didapat dari data sekunder yaitu berupa rekam medis RSUP Sanglah Denpasar yang sudah memenuhi kriteria inklusi dan eksklusi.

Tabel 1 menunjukkan distribusi dari karakteristik sampel. Distribusi dari jenis kelamin baik laki - laki maupun perempuan tidak terlalu berbeda. Dalam kategori usia, variabel usia dikategorikan menjadi beberapa klasifikasi, yaitu (1) bayi ( $<2$ tahun); (2) balita (2-5 tahun); (3) anak (5-12 tahun); (4) remaja (>12 tahun). Kategori usia bayi merupakan yang tertinggi pada sampel yang digunakan, yaitu $57,1 \%$. Diagnosis terbanyak adalah syok sepsis sebesar $60,7 \%$.

Nilai sentral sampel tertera pada Tabel 2. Median dari usia didapatkan 0,875 dengan rentangan dari 0,08-17,00 tahun. Lama rawat UPIA yang didapatkan dari 1-36 hari dengan nilai median dari skor PELOD-2, yaitu 6,0. Nilai rerata laboratorium dari sampel, yaitu white blood cell (WBC) dan platelet (PLT) masing-masing 37,38 dan 245,20. Skor pediatric sequential failure assesment (pSOFA) didapatkan dengan rerata 5,94.

Distribusi kategori usia berdasarkan karakteristik sampel tertera pada Tabel 3 Didapatkan bayi berjenis kelamin perempuan lebih banyak dibandingkan pada laki - laki $(73,3 \%$ vs 38,5\%). Status nutrisi ter banyak adalah gizi baik (64,7\%). Tujuh belas sampel didiagnosis dengan syok sepsis. Bayi terdiagnosis dengan syok sepsis sebesar 70,6\%. Luaran pada kategori usia bayi antara yang meninggal dan hidup tidak ada perbedaan yang bermakna.

Tabel 4 menunjukkan distribusi luaran berdasarkan diagnosis pada UPIA, 30,0\% meninggal dengan terdiagnosis sepsis. Syok sepsis merupakan diagnosis terbanyak, didapatkan jumlah yang meninggal $47,1 \%$.

Tabel 5 menunjukkan distribusi luaran berdasarkan keterlibatan organ, 58,3\% memiliki keterlibatan tiga organ dan meninggal.

\section{Pembahasan}

Kriteria diagnosis untuk sepsis dan sepsis yang berat mengalami perbaikan dari waktu ke waktu. Definisi sepsis pada awalnya dibuat pada tahun 1991 dengan berdasarkan pada pemahaman mengenai systemic inflamatory response syndrome yang ditandai dengan adanya dua atau lebih gejala, seperti suhu yang lebih dari 38 atau kurang dari 36, laju jantung lebih dari 90
Tabel 1. Karakteristik sampel

\begin{tabular}{|c|c|c|}
\hline Karakteristik & Frekuensi & Persentase \\
\hline \multicolumn{3}{|l|}{ Jenis kelamin } \\
\hline Laki - Laki & 13 & 44,0 \\
\hline Perempuan & 15 & 56,0 \\
\hline \multicolumn{3}{|l|}{ Kategori usia } \\
\hline Bayi & 16 & 57,1 \\
\hline Balita & 4 & 14,3 \\
\hline Anak & 7 & 25,0 \\
\hline Remaja & 1 & 3,6 \\
\hline \multicolumn{3}{|l|}{ Bulan masuk } \\
\hline Tiga & 1 & 3,6 \\
\hline Empat & 2 & 7,1 \\
\hline Lima & 6 & 21,4 \\
\hline Enam & 1 & 3,6 \\
\hline Tujuh & 3 & 10,7 \\
\hline Delapan & 1 & 3,6 \\
\hline Sembilan & 3 & 10,7 \\
\hline Sepuluh & 4 & 14,3 \\
\hline Sebelas & 3 & 10,7 \\
\hline Duabelas & 4 & 14,3 \\
\hline \multicolumn{3}{|l|}{ Status nutrisi } \\
\hline Gizi lebih & 1 & 3,6 \\
\hline Gizi baik & 17 & 60,7 \\
\hline Gizi kurang & 10 & 35,7 \\
\hline \multicolumn{3}{|c|}{ Diagnosis pada PICU } \\
\hline SIRS & 0 & 0 \\
\hline Infeksi & 1 & 3,6 \\
\hline Sepsis & 10 & 35,7 \\
\hline Sepsis berat & 0 & 0 \\
\hline Syok sepsis & 17 & 60,7 \\
\hline \multicolumn{3}{|l|}{ Luaran } \\
\hline Meninggal & 11 & 39,3 \\
\hline Hidup & 17 & 60,7 \\
\hline \multicolumn{3}{|c|}{ Keterlibatan organ } \\
\hline Satu & 5 & 17,9 \\
\hline Dua & 10 & 35,7 \\
\hline Tiga & 12 & 42,9 \\
\hline Lebih dari 3 & 1 & 3,6 \\
\hline \multicolumn{3}{|l|}{ Kultur } \\
\hline Positif & 8 & 28,6 \\
\hline Negatif & 20 & 71,4 \\
\hline
\end{tabular}

kali permenit, laju nafas lebih dari 20 kali permenit atau PaCO2 kurang dari $32 \mathrm{mmHg}$ dan White Blood Cell lebih dari 12.000 per $\mu \mathrm{L}$ atau kurang dari 400 sel per $\mu L$. Pada tahun 2001, definisi awal ini dikembangkan 
Tabel 2. Rentang nilai variabel

\begin{tabular}{lc}
\hline Variabel & Nilai \\
\hline Usia, tahun, median (IQR) & $0,875(6,48)$ \\
Berat badan, kilogram, median (IQR) & $7,05(18,23)$ \\
Tinggi badan, cm, median (IQR)) & $65,5(61,50)$ \\
Lama rawat UPIA, hari, median (IQR) & $10(10)$ \\
Skor PELOD-2, median (IQR) & $6,0(8)$ \\
Prokalsitonin, ng/ml, median (IQR) & $7,66(24,01)$ \\
Tekanan sistolik, mmHg, rerata (SB) & $95,79 \pm 21,70$ \\
Tekanan diastolik, mmHg, rerata (SB) & $52 \pm 15,54$ \\
RR (x/menit), rerata (SB) & $42,79 \pm 11,51$ \\
HR (x/menit), rerata (SB) & $138,54 \pm 27,61$ \\
Suhu tubuh, ${ }^{\circ} \mathrm{C}$, rerata (SB) & $37,38 \pm 0,97$ \\
WBC, rerata (SB) & $19,79 \pm 13,42$ \\
PLT, rerata (SB) & $245,20 \pm 183,65$ \\
Skor pSOFA, rerata (SB) & $5,94 \pm 2,79$ \\
\hline
\end{tabular}

Tabel 3. Distribusi kategori usia berdasarkan karakteristik sampel

\begin{tabular}{|c|c|c|c|c|c|}
\hline \multirow{2}{*}{ Karakteristik } & \multicolumn{4}{|c|}{ Kategori usia (\%) } & \multirow{2}{*}{ Total } \\
\hline & Bayi & Balita & Anak & Remaja & \\
\hline \multicolumn{6}{|l|}{ Jenis kelamin } \\
\hline Laki - laki & $5(38,5)$ & $2(15,4)$ & $5(38,5)$ & $1(7,7)$ & $13(100,0)$ \\
\hline Perempuan & $11(73,3$ & $2(13,3)$ & $2(13,3)$ & $0(0,0)$ & $15(100,0)$ \\
\hline \multicolumn{6}{|l|}{ Status nutrisi } \\
\hline Gizi lebih & $0(0,0)$ & $1(100,0)$ & $0(0,0)$ & $0(0,0)$ & $1(100,0)$ \\
\hline Gizi baik & $11(64,7)$ & $1(5,9)$ & $4(23,5)$ & $1(5,9)$ & $17(100,0)$ \\
\hline Gizi kurang & $5(50,0)$ & $2(20,0)$ & $3(30,0)$ & $0(0,0)$ & $10(100,0)$ \\
\hline \multicolumn{6}{|c|}{ Diagnosis pada UPIA } \\
\hline Infeksi & $0(0,0)$ & $0(0,0)$ & $1(100,0)$ & $0(0,0)$ & $1(100,0 \%)$ \\
\hline Sepsis & $4(40,0)$ & $1(10,0)$ & $4(40,0)$ & $1(10,0)$ & $10(100,0)$ \\
\hline Syok sepsis & $12(70,6)$ & $3(17,6)$ & $2(11,8)$ & $0(0,0)$ & $17(100,0)$ \\
\hline \multicolumn{6}{|l|}{ Luaran } \\
\hline Meninggal & $6(54,5)$ & $2(18,2)$ & $3(27,3)$ & $0(0,0)$ & $11(100,0)$ \\
\hline Hidup & $10(58,8)$ & $2(11,8)$ & $4(23,5)$ & $1(5,9)$ & $17(100,0)$ \\
\hline \multicolumn{6}{|c|}{ Keterlibatan organ } \\
\hline Satu & $4(80,0)$ & $0(0,0)$ & $1(20,0)$ & $0(0,0)$ & $5(100,0)$ \\
\hline Dua & $4(40,0)$ & $2(20,0)$ & $3(30,0)$ & $1(10,0)$ & $10(100,0)$ \\
\hline Tiga & $7(0,0)$ & $2(16,7)$ & $3(25,0)$ & $0(0,0)$ & $12(100,0)$ \\
\hline Lebih dari 3 & $1(100,0)$ & $0(0,0)$ & $0(0,0)$ & $0(0,0)$ & $1(100,0)$ \\
\hline \multicolumn{6}{|l|}{ Hasil kultur } \\
\hline Positif & $5(62,5)$ & $0(0,0)$ & $3(37,5)$ & $0(0,0)$ & $8(100,0)$ \\
\hline Negatif & $11(55,0)$ & $4(20,0)$ & $4(20,0)$ & $1(5,0)$ & $20(100,0)$ \\
\hline
\end{tabular}


Tabel 4. Distribusi luaran berdasarkan diagnosis pada UPIA

\begin{tabular}{|c|c|c|c|}
\hline \multirow{2}{*}{ Diagnosis pada UPIA } & \multicolumn{2}{|c|}{ Luaran (\%) } & \multirow{2}{*}{ Total } \\
\hline & Meninggal & Hidup & \\
\hline Infeksi & $0(0,0)$ & $1(100,0)$ & $1(100,0)$ \\
\hline Sepsis & $3(30,0)$ & $7(70,0)$ & $10(100,0)$ \\
\hline Syok sepsis & $8(47,1)$ & $9(52,9)$ & $17(100,0)$ \\
\hline
\end{tabular}

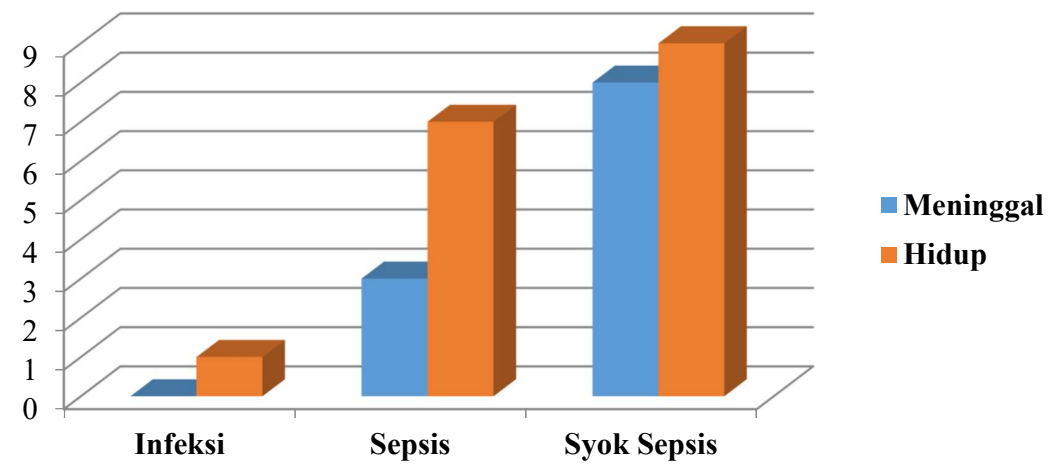

Gambar 1. Distribusi luaran berdasarkan diagnosis pada UPIA

Tabel 5. Distribusi luaran berdasarkan keterlibatan organ

\begin{tabular}{lccc}
\hline \multirow{2}{*}{ Keterlibatan organ } & \multicolumn{2}{c}{ Luaran (\%) } & \multirow{2}{*}{ Total } \\
\cline { 2 - 3 } & Meninggal & Hidup & $5(100,0)$ \\
Satu & $1(20,0)$ & $7(80,0)$ & $10(100,0)$ \\
Dua & $3(30,0)$ & $5(41,7)$ & $12(100,0)$ \\
Tiga & $7(58,3)$ & $1(100,0)$ & $1(100,0)$ \\
Lebih dari tiga organ & $0(0,0)$ & & \\
\hline
\end{tabular}

kembali dengan menambah beberapa variabel, seperti kondisi inflamasi, kondisi hemodinamik, disfungsi organ, dan perfusi jaringan. Pengembangan ini selanjutnya di rekomendasikan dan diadopsi oleh surviving sepsis campaign (SSC) pada tahun 2004, 2008, dan 2012. Pada tahun 2014, terjadi pengembangan terhadap definisi sepsis oleh satuan tugas penanganan sepsis dan menyimpulkan untuk menghilangkan definisi sepsis berat dan merekomendasikan skor sequential failure assesment (SOFA) >2 sebagai definisi baru sepsis. Tujuan penyempurnaan definisi ini adalah memudahkan para ahli dalam mendiagnosis dan mengurangi waktu dalam mendiagnosis sehingga pasien dengan kondisi sepsis dan memiliki prognosis buruk segera mendapatkan penanganan. ${ }^{10}$

Semakin hari, skor SOFA yang hanya bisa diaplikasikan pada pasien dewasa semakin mengalami penyempurnaan sehingga dilakukan proses validasi dan adaptasi pada pasien anak dengan nama pediatric SOFA (pSOFA). ${ }^{10-11}$

Di Indonesia sendiri, Ikatan Dokter Anak Indonesia (IDAI) memplikasikan pedoman diagnosis sepsis berdasarkan adanya infeksi dan tanda disfungsi organ. Disfungsi organ dinilai berdasarkan skor pediatric logistic organ dysfunction-2 (PELOD-2). Diagnosis sepsis ditegakkan bila skor PELOD-2 $\geq 11$ (pada rumah sakit tipe $A$ ), atau $\geq 7$ pada layanan kesehatan tipe B atau C. Skor pSOFA sendiri mendapatkan penyesuaian untuk sistem kardiovaskular dan sistem renal berdasarkan skor PELOD-2. ${ }^{11}$ Penelitian yang dilakukan Gogia dkk memprediksi kematian pada pasien anak sakit kritis di ruang rawat intensif anak di India berdasarkan skor pSOFA pada 72 jam perawatan secara statistik berhubungan dengan prognosis dalam memprediksi mortalitas, sama baik dengan skor PELOD-2, dengan sensitifitas 96\%, spesifisitas 98\%, 
positive predictive value $90 \%$, dan negative predictive value $99 \% .{ }^{10}$

Rerata skor pSOFA (SB) 5,94 (2,79) dengan anak pada kondisi sepsis dan syok sepsis 27 sampel dari total sampel. Hal ini menunjukkan bahwa skor pSOFA mampu memberikan prediksi bahwa anak akan jatuh pada kondisi sepsis pada pasien anak dengan kondisi kritis di UPIA RSUP Sanglah Denpasar.

Rerata skor pSOFA tersebut menghasilkan luaran $30,0 \%$ pasien meninggal. Peningkatan nilai skor pSOFA $\geq 2$ diketahui meningkatkan risiko kematian antara $1,9 \%$ hingga $7,6 \%$. Risiko mengalami luaran sekunder pun meningkat antara $17,6 \%$ sampai $46,1 \% .^{12}$

Pada penelitian kami, prevalensi anak yang mengalami sepsis pada usia 0 tahun hingga 18 tahun sebesar 35,7\% dan yang mengalami kondisi syok sepsis $60,7 \%$. Kelompok usia bayi merupakan kelompok usia terbanyak dengan diagnosis syok sepsis, yaitu 70,6\%. Hasil ini berbeda dengan penelitian oleh Southeast Asia Infectious Disease Clinical Research Network ${ }^{10}$ yang melaporkan kelompok usia balita merupakan kelompok usia yang paling banyak terdiagnosis syok sepsis. Perbedaan ini kemungkinan disebabkan oleh jumlah sampel penelitian yang lebih banyak dan melibatkan lebih dari satu pusat pendidikan dan penelitian. Selain itu, terdapat perbedaan definisi usia bayi dan usia anak pada penelitian kami dengan penelitian tersebut. Pada penelitian kami, usia bayi didefinisikan dengan usia $<2$ tahun dan balita berusia 2-5 tahun. Sementara pada penelitian tersebut usia bayi didefinisikan dengan usia 30 hari -1 tahun dan balita berusia 1-5 tahun.

Pada penelitian yang melibatkan 128 di sentra pendidikan dan penelitian pada 26 negara mendapatkan pasien dengan median (IQR) berusia tiga $(0,7-$ $11,0)$ tahun. ${ }^{13}$ Tidak jauh berbeda dengan penelitian kami yang mendapatkan median (IQR) pasien berumur 0,875 (IQR) tahun atau kurang lebih 10,5 bulan.

\section{Kesimpulan}

Prevalensi sepsis dan klasifikasi pasien anak usia 0-18 tahun di RSUP Sanglah Denpasar tahun 2018 didominasi oleh pasien dengan kategori usia bayi $(<2$ tahun), yaitu sebesar $57,1 \%$. Diagnosis terbanyak adalah syok sepsis (60,7\%). Dominasi pasien sepsis dan septik syok ini didukung dengan skor rerata pSOFA (SB) 5,94 (2,79). Namun begitu, perlu dilakukan penelitian lebih lanjut untuk menguji hubungan antara skor pSOFA dengan kejadian dan luaran pasien sepsis di UPIA di RSUP Sanglah Denpasar.

\section{Daftar pustaka}

1. Goldstein B, Giroir B, Randolph A. Sepsis ICCoP. International pediatric sepsis consensus conference: definitions for sepsis and organ dysfunction in pediatrics. Pediatr Crit Care Med 2005;6:2-8.

2. Kawasaki, T. Update on pediatric sepsis: a review. J IC 2017;5:47Weiss SL, Fitzgerald JC, Pappachan J, dkk. Global epidemiology of pediatric severe sepsis: the sepsis prevalence, outcomes, and therapies study. Am J Respir Crit Care Med 2015;191:1147-57.

3. de Oliveira CF, de Oliveira DSF, Gottschald AFC, dkk. ACCM/PALS haemodynamic support guidelines for paediatric septic shock: an outcomes comparison with and without monitoring central venous oxygen saturation. Intensive Care Med 2008;34:1065-75.

4. Irawan, Danny, Hamidah, Purwati, EA Triyono, Brahmantono, V Arfianto, dkk. Profil penghasil penderita sepsis akibat bakteri penghasil ESBL. J Peny Dalam 2012;13:63-8.

5. Riset Kesehatan Dasar (Riskesdas). Badan Penelitian dan Pengembangan Kesehatan Kementerian RI tahun 2013. Diakses 6 September 2018. Didapat dari: http://www.depkes. go.id/resources/download/general/Hasil\%20Riskesdas\% 013. $p d f$.

6. Bone RC, Balk RA, Cerra FB, dkk. Definitions for sepsis and organ failure and guidelines for the use of innovative therapies in sepsis. The ACCP/SCCM Consensus Conference Committee. American College of Chest Physicians/Society of Critical Care Medicine. Chest 1992;101:1644-55.

7. Levy MM, Fink MP, Marshall JC, dkk. SCCM/ESICM/ ACCP/ ATS/SIS International Sepsis Defi nitions Conference. Crit Care Med 2003;31:1250-6.

8. Singer M, Deutschman CS, Seymour CW, dkk. The third international consensus definitions for sepsis and septic shock (sepsis-3). JAMA 2016;315:801-10.

9. Southeast Asia Infectious Disease Clinical Research Network. Causes and outcomes of sepsis in southeast Asia: a multinational multicentre cross-sectional study. The Lancet Global Health 2017;5:157-67.

10. Wulandari, Anindita, Martuti Sri, Kaswadi, Pudjiastuti. Perkembangan diagnosis sepsis pada anak. Sari Pediatri 2018;19:237-44. 
11. Schlapbach LJ, Straney L, Bellomo R, MacLaren G, Pilcher D. Prognostic accuracy of age-adapted SOFA, SIRS, PELOD-2, and qSOFA for in-hospital mortality among children with suspected infection admitted to the intensive care unit. ICM 2018;44:179-88.

12. Weiss SL, FitzgeraldJC, PappachanJ, Wheeler D, Jaramillo-
Bustamante J C, Salloo A, dkk. Sepsis prevalence, outcomes, and therapies (SPROUT) study investigators and pediatric acute lung injury and sepsis investigators (PALISI) Network. Global epidemiology of pediatric severe sepsis: the sepsis prevalence, outcomes, and therapies study. Am J RespirCrit Care Med 2015;191:1147-57. 